\title{
Explaining Authentic Leadership Work Outcomes from the Perspective of Self-Determination Theory
}

\begin{abstract}
The article examines the impact of authentic leadership in leader-follower relationship conceptualized from self-determination theory perspective. Authentic leadership enhances followers' intrinsic motivation, trust in organisation, commitment and overall job satisfaction. Intrinsic motivation of leaders' fosters internalization of authentic leadership values among employees. The intrinsically oriented followers are more engaged in effective authentic leader-follower relations, than the followers who possess extrinsic work value orientation. Authentic leadership relevance can be explained by followers' intrinsic or extrinsic work value orientation.
\end{abstract}

Keywords: Authentic leadership, self-determination theory, intrinsic / extrinsic motivation, trust.

Šio straipsnio tikslas - išanalizuoti Self-determination (liet. Apsisprendimo) ir Autentiškos lyderystès sąvokas, teoriškai nustatyti ir ịvertinti autentiškos lyderystès pasekmes dvipusiame lyderio-pasekèjo ryšyje, remiantis Self-determination teorija. Autentiška lyderystė gali didinti pasekèjų vidinę motyvaciją, pasitikẻjimą organizacija ir bendrą pasitenkinimą darbu. Didejanti vidinè lyderių motyvacija skatina autentiškos lyderystès vertybių internalizaciją tarp organizacijos darbuotojų. Autentiškos lyderystès poveikis priklauso nuo pasekejų vidinès ar išorinès darbo vertybinès orientacijos.

Raktiniai žodžiai: autentiška lyderystè, self-determination (apsisprendimo) teorija, vidinè / išorinè motyvacija, pasitikejimas.

\section{Introduction}

The construct of authentic leadership arose at the end of 20th century as a new leadership form which focuses on being ethical and being authentic - being true to yourself and your followers. The concept of authentic leadership occurred in the evidence of the crisis of confidence in contemporary corporate leadership (Avolio \& Gardner,
2005; Cooper et al., 2005) and was seen the kind of leadership that can restore confidence and hope in the organizations (Sparrow, 2005), contribute to follower development.

Self-determination theory is also relatively new, being developed from the end of $20^{\text {th }}$ century (Deci \& Ryan, 2002). Both theories impose attitude towards people as human beings who possess an active

Alisa MINIOTAITÉ - Doctoral Student, ISM University of Management and Economics. Address: Arklių St. 18, Vilnius LT-01129. Tel.: 003705203 4408. E-mail: minialis@stud.ism.lt. Research field: organizational behaviour \& leadership.

Ilona BUČIŪNIENE் - Professor, ISM University of Economics and Management. Address: E. Ožeškienės St. 18, Kaunas LT-44254. Tel.: 0037037302 405. E-mail: ilobuc@ism.lt. Research field: human resource management. 
tendency towards psychological growth (Novicevic et al. 2006; Avolio \& Gardner, 2005; Ryan \& Deci, 2002), and put efforts to disclose basic human needs. While authentic leadership theory, including but not limited, tries to explain the leaders and followers' needs, self-determination theory focuses on people's basic psychological needs and motivations.

Until 2008, the researches of authentic leadership school proposed merely theoretical models and focused on the determination of authentic leadership construct and scale. The most critical issues with respect to authentic leadership theory were determined by F. O. Walumbwa et al. (2008), M. M. Novicevice et al. (2006), C. D. Cooper et al. (2005): defining and measuring the construct; determining the discriminant validity of the construct; identifying relevant construct outcomes. The outcomes of authentic leadership, such as impact of authentic leadership to organizational performance, employee engagement, well-being, withdrawal behaviours and others have not received enough scholars' attention (Jensen \& Luthans, 2006; Gardner et al., 2005; Ilies et al., 2005 Avolio et al., 2004). This article contributes to the development of authentic leadership theory by conceptualizing the outcomes of authentic leadership from self-determination theory perspective.

\section{Authentic leadership theory}

Theory of authentic leadership has emerged from the intersection of leadership, ethics, and positive organizational behaviour (Walumbwa et al., 2008). The origins of authentic leadership concept can be explained from social, humanistic and existential psychology perspective (Walumbwa et al., 2008; Novicevic et al., 2006; Avolio \& Gardner, 2005); from positive organizational behavior theory (Gardner \& Schermerhorm, 2004; Jensen \& Luthans, 2006; Verbos et al., 2007; Walumbwa et al, 2008), as well as other leadership studies (George et al., 2007; Shirey, 2006; Shamir \& Eilam, 2005; Novicevic et al., 2005; 2006; Sparrow, 2005; George, 2003). Scholars agree that common in concept of authentic leadership is the idea of actions and behaviours' alignment with the core, internalized values and beliefs (Harvey et al., 2006). F. O. Walumbwa et al. (2008) propose "authenticity means owning one's personal experience, be they thoughts, emotions, needs, preferences or beliefs, processes captured by the injunction to know oneself and behaving in accordance with the true self".

\section{Self-determination theory}

Self-determination theory (SDT) was developed drawing from psychoanalytic, humanistic and cognitive theories of human development, as well as studies comparing the intrinsic and extrinsic motivation. SDT approves both the humanistic approach towards organismic development, as well as post-modern approach that see human nature as lacking such an endowment, and integrates the phenomena of these viewpoints (Ryan \& Deci, 2002). Although SDT accepts the idea of organismic growth coming from humanistic psychology, the scholars consider social and contextual factors as well. This is not contradictory to humanistic psychology, as both A. H. Maslow (1970) and C. R. Rogers (1980) explained social influence in human development. 
According to E. L. Deci \& R. M. Ryan (2002), self-determination theory is a theory of human motivation which focuses on active, growth oriented human organism and social contexts that either support or undermine people's attempts to master and integrate their experiences into a coherent sense of self. SDT concentrates on the degree to which individual's behaviour is self-endorsed and selfdetermined.

The key studies of SDT focus on intrinsic and extrinsic motivation (Deci \& Ryan, 2000). The concept of intrinsic motivation refers to behaviours performed out of interest and enjoyment, whereas extrinsic motivation means behaviors carried out to attain contingent outcomes (Vallerand \& Ratelle, 2002). Scholars of self-determination theory identified four types of extrinsic motivation that vary in degree of self-determination and autonomy, beginning from non-self-determined to self-determined extrinsic motivation: (i) external regulation, (ii) introjected regulation, (iii) identified regulation, (iv) amotivation.

Three main intrinsic needs that motivate the self to initiate behavior and contribute to psychological health and wellbeing of an individual are: (i) the need for competence, (ii) the need for autonomy and (iii) the need for relatedness (Ryan \& Deci, 2002). The need for autonomy refers to individual's need to experience the initiation, maintenance and control of behavior. The need for competence refers to individuals need to succeed at challenging tasks and to achieve desired outcomes. The need for relatedness refers to the need of establishment a connection with important others (Luyckx et al., 2008). The optimal outcomes are attained when these three needs are balanced, i.e. equally satisfied (Vallerand et al., 2008).

\section{Theoretical Concurrence between the Theories}

SDT states that conditions necessary for growth and well-being of people's personalities and cognitive structures are competence, relatedness and autonomy. The theory proposes that the tendency towards growth will function if these needs are fulfilled (Hodgins \& Knee, 2002).

Drawing from the perspective of humanistic psychology, authentic leadership theory bases on human self-actualization (Walumbwa et al., 2008; Novicevic et al., 2006; Avolio \& Gardner, 2005) which will flourish in case the psychological needs of safety (also physiological safety), belonging and esteem are met (Maslow, 1970). Sincerity, benevolence and empathy are the preconditions for growth and development (Rogers, 1980). Both SDT, as well as the school of humanistic psychology, try to reveal essential precondition for human growth and development, and these precondition have a significant overlap. The comparison of three intersecting approaches may be seen below in Table 1 .

According to SDT theory, after basic psychological needs are satisfied, people become filled in with a sense of self-authentic and congruent intrinsic aspect of the core self (Hodgins \& Knee, 2002). This reflection is also shared among the theorists of authentic leadership school.

One of the sources of human authenticity is the freedom of self-determination. The self-determination freedom means that a human is free when he / she can decide for him / herself what is important rather than being shaped by external influences. Self-determination is explained as the default solution in culture of 
Humanistic and SDT approaches towards conditions for growth and development

\begin{tabular}{|c|c|c|}
\hline $\begin{array}{c}\text { A. H. Maslow's (1970) } \\
\text { perspective } \\
\text { of self-actualization }\end{array}$ & $\begin{array}{c}\text { C. R. Rogers's (1980) } \\
\text { perspective } \\
\text { on a fully functioning person }\end{array}$ & $\begin{array}{c}\text { SDT perspective toward growth } \\
\text { and well-being } \\
\text { (Deci \& Ryan, 2002) }\end{array}$ \\
\hline $\begin{array}{l}\text { Belonging: } \\
\text { - love, } \\
\text { - family, } \\
\text { - community. }\end{array}$ & $\begin{array}{l}\text { Empathy: } \\
\text { - acceptance by others. }\end{array}$ & $\begin{array}{l}\text { Relatedness: } \\
\text { - belongingness, } \\
\text { - connection to others, } \\
\text { - care for others. }\end{array}$ \\
\hline $\begin{array}{l}\text { Esteem: } \\
\text { - confidence, } \\
\text { - achievement, } \\
\text { - respect }\end{array}$ & $\begin{array}{l}\text { Benevolence: } \\
\text { - understanding, } \\
\text { - respect. }\end{array}$ & $\begin{array}{l}\text { Competence: } \\
\text { - effectiveness, } \\
\text { - self-expression, } \\
\text { - respect. }\end{array}$ \\
\hline $\begin{array}{l}\text { Safety: } \\
\text { - security }\end{array}$ & $\begin{array}{l}\text { Sincerity: } \\
\text { - openness }\end{array}$ & $\begin{array}{l}\text { Autonomy: } \\
\text { - perceived origin or source of one's own behavior. }\end{array}$ \\
\hline
\end{tabular}

authenticity (Taylor, 1991). Self-determination is one's behavioral and relational choice next to self-awareness and unbiased self-relevant cognitions in the construct of authenticity (Novicevic et al., 2006; Kernis, 2003).

E. L. Deci et al. (1989) refer to the self-determination as the experience of a sense of choice in initiating and relating one's own actions. The Ch. Taylor's (1991) self-determination freedom could be referred to the autonomy in self-determination theory. However, H. S. Hodgins \& C. R. Knee (2002) state that authentic self is underlying autonomy motivation as an "integrating" self. The scholars relate autonomous behavior with the following outcomes: openness, less use of stereotypic information in forming judgments, lower emotional defensiveness, acceptance of one's emotions, action in lower control oriented manner, secure self-worth, honesty, and responsibility.

Self-determination theory and authentic leadership theory significantly overlap in explanation of the concepts of autonomy and authenticity which are key to each theory. The scholars of authentic leadership propose identical qualities of authentic leadership:

- openness (Mazutis \& Slawinski, 2008; George et al, 2007; Kellett et al, 2006; Illies et al, 2005; Avolio \& Gardner, 2005);

- unbiased processing, also referred to as balanced processing (the processing of self-relevant information; involves not denying, distorting, exaggerating or ignoring private knowledge, internal experiences, and externally based evaluative information) (Walumbwa et al, 2008; Ilies et al., 2005; Kernis, 2003);

- low self-monitoring (Kernis, 2003);

- optimal self-esteem (Walumbwa et al., 2008; Novicevic et al, 2006; Avolio et al, 2005; Illies et al, 2005; Kernis, 2003);

- honesty (Novicevic et al, 2006; Kellett et al, 2006);

- responsibility (Novicevic et al., 2005; 2006; Michie \& Gooty, 2005; Barnard, 1938; 1948).

The qualities not evaluated by the selfdetermination theory, but attributed to authentic leadership are as follows: selfawareness (Endrissat et al., 2007; Eagly, 
2005; Sparrow, 2005; Shamir \& Eilam, 2005; Gardner et al. 2005; Harter, 2002; Taylor, 1991), transparency (Mazutis \& Slawinsky, 2008; Kellett et al., 2006; Shirey, 2006; Novicevic et al., 2006; Eagly, 2005; Avolio et al., 2005), optimism (Verbos et al., 2007; Harvey et al, 2006; Gardner \& Shermerhorn, 2004; Avolio et al., 2004), resiliency (Verbos et al., 2007; Norman et al, 2005; Gardner \& Shermerhor, 2004), displaying hope (Verbos et al., 2007; Harvey et al., 2006; Norman et al., 2005; Illies et al., 2005; Avolio et al., 2004; Gardner \& Shermerhor, 2004), effectiveness (Avolio et al., 2009; Walumbwa et al., 2008; Endrissat et al, 2007; Kellett et al., 2006), high level of energy (Shamir \& Eilam, 2005), strength (Shamir \& Eilam, 2005), empathy (Kellett et al, 2006; Harvey et al., 2006), confidence (Verbos et al., 2007; George et al, 2007; Novicevic et al., 2006; Illies et al, 2005), future-orientation (Verbos et al., 2007; Jensen \& Luthans, 2006; Avolio et al., 2004), intuition (Novicevic et al, 2006), follower-orientation (Verbos et al., 2007; Novicevic et al., 2006; Illies et al., 2005). The qualities related to values, ethics and morals are the ones especially distinguishing the authentic leadership theory from SDT: knowing your values (Walumbwa et al, 2008; Verbos et al, 2007; Endrissat et al., 2007; Shirey, 2006; Harvey et al., 2006;), integrity (Endrissat et al., 2007; Verbos et al., 2007; Kellett et al., 2006; Shamir and Eilam, 2005), moral creativity (Novocevic et al., 2006).

Significant community between the self-determination and authentic leadership theories suggests that propositions conceptualized from the more researched self-determination theory could serve for the development and investigation of authentic leadership theory.

\section{Intrinsic and extrinsic motivation}

A. H. Maslow (1970) and SDT researchers agree that satisfaction of higher order needs promotes effective performance (Deci et al., 1989). This idea is explained by the Cognitive Evaluation Theory (CET) within SDT. CET suggests that feelings of autonomy and competence positively affect intrinsic motivation. Intrinsic motivation refers to "the innate energy that people demonstrate when they pursue a goal or an activity because it is interesting or fun” (Koestner \& Losier, 2002). P. B. Baard (2002) and R. M. Ryan \& E. L. Deci (2000) describe intrinsic motivation as "inherent tendency to seek out novelty and challenges, to extend and exercise one's capacities, to explore, and to learn". Being intrinsically motivated means doing the activity itself, with satisfaction and meaning, and with the reasons coming from within.

Extrinsic motivation is characterized as originating from instrumental reasons rather than from inherent sources (Vallerand \& Ratelle, 2002). Extrinsic motivation describes "doing an activity with a focus on some separable outcome, rather than engaging in it for its inherent satisfaction" (Baard, 2002).

Intrinsic motivation is associated with better work performance (Kuvaas, 2006a; 2006b), persistence (Deci \& Ryan, 2008), higher levels of satisfaction and creativity (Baard, 2002), increased level of trust in corporate management, organizational commitment (Gagne \& Deci, 2005), selfesteem (Vansteenkiste et al., 2007). While extrinsic motivation may raise emotional exhaustion and short-lived satisfaction and negatively predicts well-being and self-actualization (Vansteenkiste et al., 2007).

The issue of enhancing employees' intrinsic motivation receives high attention 
from researchers. One of the related issues is the effect of extrinsic motivators on intrinsic motivation. The availability of choice, competence accompanied by personal control over performance and applied rewards which are perceived as noncontrolling increase intrinsic motivation (Ilies et al., 2005). E. L. Deci et al. (1999) specify that unexpected rewards enhance intrinsic motivation. Other researches, however, show that tangible rewards, such as money or awards, deadlines, surveillance and anticipated evaluation decrease intrinsic motivation (Gagne \& Deci, 2005; Ilies et al, 2005; Ryan \& Deci, 2002).

Controversial data is received about another extrinsic motivator - feedback (Ryan \& Deci, 2002). Verbal rewards are expected to enhance intrinsic motivation as they provide an affirmation of competence (Deci et al., 1999). However, empirical evidence shows twofold influence of feedback on intrinsic motivation. First, positive feedback facilitates intrinsic motivation by providing a sense of confidence, while the negative feedback undermines intrinsic motivation leaving a person amotivated (Gagne \& Deci, 2005). Secondly, verbal reward, even positive, can have a significant controlling component and thus has the power to undermine intrinsic motivation. The evidence shows that controlling positive feedback leads to less intrinsic motivation than informational positive feedback (Deci et al., 1999).

\section{Explaining authentic leadership outcomes from the perspective of self-determination theory}

Leader-followers' relations. Scholars agree that outcomes of authentic leadership remain unexplored theoretically and empirically. However, there is a theoretical agreement that authentic leaders stimulate followers' identification (Avolio et al., 2004) and foster followers' authenticity, i.e. self-awareness and self-regulation (Avolio \& Gardner, 2005). Research by F. O. Walumbwa et al. (2008) shows positive affect of authentic leadership on job performance and job satisfaction, however there is no empirical evidence on other outcomes of authentic leadership, such as follower development, trust, relatedness, psychological safety. One of the objectives of the F. O. Walumbwa et al.'s (2008) study was to contribute to the development and validation of authentic leadership construct. The scholars used R. Ilies et al. (2005) and W. L. Gardner et al.s (2005) conceptualizations of the construct of authentic leadership, as well as M. H. Kernis's (2003) work on optimal self-esteem. The model includes elements of: (i) self-awareness, (ii) unbiased processing (balanced processing), (iii) relational transparency, (iv) authentic behavior, (v) internalization, and (vi) positive moral perspective. The latter three components were further developed into a single dimension of 'internalized moral perspective.' Self-awareness is seen as an essential quality of authentic leadership, referring to knowing oneself, trusting oneself, knowing your values, motives, feelings and cognitions (May et al., 2003; Illies et al., 2005). Unbiased processing refers to "the processing of self-relevant information and involves not denying, distorting, exaggerating or ignoring private knowledge, internal experiences, and externally based evaluative information" (Illies et al, 2007; Kernis, 2003). The component of authentic behaviour refers to "acting in accord with one's true self, one's own values, preferences and needs as opposed to acting merely to 
please others or to attain rewards or avoid punishment though acting "falsely" (Illies et al., 2005; Kernis, 2003). Internalized moral perspective refers to an internalized and integrated form of self-regulation (Walumbwa et al., 2008).

Researches on SDT indicate relationship between managerial support and positive employees' work outcomes (Kuuvas, 2009; Gagne \& Deci, 2005). The support for employee autonomy expressed by the supervisors, i.e. acknowledging subordinates' perspectives, providing relevant information in a non-controlling way, offering choice, has a positive effect on employees' satisfaction, level of trust in corporate management, and displays other positive work related outcomes (Gagne \& Deci, 2005).

The behaviour of authentic leader followed by self-awareness, unbiased processing, relational transparency and internalized moral perspective leads to the process of followers' identification, positive emotional contagion, positive behavioural modeling, social exchanges and self-determination (Ilies et al., 2005). According to E. L. Deci et al. (1989), support for employees' self-determination increases trust in organization, satisfaction with quality of feedback, opportunity for inputs, security, and favourable work atmosphere and overall job satisfaction. Leader's behaviour fostering autonomous motivation increases employee life satisfaction. There is a relation between goal attainment and life satisfaction: when employees are autonomously motivated in pursuing self-generated goals, there is a strong relation between goal attainment and life satisfaction. Whereas, when employees are more controlled in their goal pursuits, there is no relation between goal attainment and life satisfaction (Gagne \&
Deci, 2005). Thus authentic leadership by supporting follower autonomy and selfdetermination leads to increase of followers' intrinsic motivation, trust, organizational commitment and job satisfaction.

Following the above theoretical reasoning, the propositions can be made as follows:

Proposition 1: Authentic leadership increases followers' intrinsic motivation.

Proposition 2: Authentic leadership increases followers' trust, organization commitment and overall job satisfaction.

Leaders' satisfaction and performance. Self-determination theory empowers not only to define the positive impact of authentic leaders' behavior on follower autonomy, but also the effect of such behaviour for leaders themselves. The essence of authentic leadership lays in discovering and developing oneself from within. Those leaders, who chose leadership from the call from within and engage in their activity with passion, will be intrinsically motivated, therefore will face higher job satisfaction and overall well-being as defined by SDT. Also such leaders will be better leading by example, will foster autonomy and self-determination in their followers. Thus the third proposition is made:

Proposition 3: Authentic leaders are more likely to be intrinsically motivated.

Internalized extrinsic motivation. It is possible to be autonomously extrinsically motivated (Ryan \& Deci, 2002). The distinction between intrinsic motivation and internalized extrinsic motivation lies in the way people become drawn to engage in a given activity (Koestner \& Losier, 2002). When extrinsic motivation is more self-regulated, it shares with intrinsic motivation the quality of being autonomous (Baard, 2002). Internalization refers to the natural tendency of integration of 
socially-valued regulations that are initially perceived as being external. Successful internalization increases followers' responsibility and conscientious behavior (Koestner \& Losier, 2002).

Autonomy supportive work environments and managerial styles promote full internalization of extrinsic motives (Kuuvas, 2009; Gagne \& Deci, 2005) and this, in turn, leads to organizational commitment and psychological well-being (Gagne \& Deci, 2005). Work climates, which support autonomy, employ followers' perspective, provide greater choice and foster self-initiation, and enhance not only intrinsic, but also autonomous extrinsic motivation. The meaningful rationale behind the leaders' performance fosters people to internalize the values and regulations of the behavior.

The need for relatedness plays a central role in internalization of values (Gagne \& Deci, 2005). The interdependence and identification among employees may have a positive effect on internalization of autonomous motivation.

Authentic leadership, which is wealthy in self-awareness, acceptance of oneself and others, openness and trust, creates genuine relations in organizations (Kernis, 2003). Authentic leaders and followers engage in open and positive exchanges and share complementary goals that reflect deeply held and overlapping values (Avolio et al, 2005). Such authentic relations are considered to be resilient and enduring (George et al., 2007; Gardner \& Avolio, 2005). Therefore, we raise the proposition:

Proposition 4. Authentic leadership fosters internalization of values among employees.

Intrinsic and extrinsic work value orientations. Work value orientation may be defined as "work-related reinforcement preferences or tendencies to value specific types of incentives in the work environment" (Vansteenkiste et al., 2007). Employees of intrinsic work value orientation tend to be oriented towards self-actualization and self-expression. Intrinsically oriented employees tend to build meaningful and satisfying relations with colleagues and help people in need. Extrinsically oriented employees tend to be focused on security and tangible acquisition, such as prestige, status, and high income. The pursuit of tangible rewards lies within the anticipated personal admiration and self-worth that can be obtained by social approval and external rewards (Vansteenkiste et al., 2007).

Extrinsic work value orientation negatively predicts dedication, job vitality and job satisfaction, and positively correlates to short-lived satisfaction, emotional exhaustion and turnover intention. People, who endorse extrinsic life values, are less likely to connect with others in a close, authentic and interpersonally trusting way. The extrinsic work value orientation indicates the lower life satisfaction, feeling of emptiness, impediment of the development of a satisfying family life (Vansteenkiste et al., 2007).

Intrinsically work value oriented employees engage in activities that satisfy their basic needs, therefore a growth-promoting role is fulfilled. Employees with intrinsic work value orientation tend to take initiative and responsibility for their work, relate to other people in authentic way and thus experience sense of participation and connectedness to others.

M. Vansteenkiste et al. (2007) describe people with extrinsic work value orientation as coping with the fulfilment of their basic needs identified by the humanistic 
psychologists (Maslow, 1970), and they have lower self-esteem. M. H. Kernis (2003) relates low (or fragile) self-esteem with the self-protective and self-enhancement strategies that employ the pursuit of tangible rewards. M. Vansteenkiste et al. (2007) indicate the intrinsic work value orientation as a sign of authenticity, while Kernis relates authenticity with optimal self-esteem and vice versa. The research of H. Murphy (2003) proves there is a positive relationship between intrinsic motivation and self-esteem.

The impact of authentic leadership on follower work outcomes in relation to follower type has not been identified yet. Even if leaders carry out their role in a manner that reflects their values and convey these values effectively, followers' cooperation and identification does not necessarily follow (Eagly, 2005). Leadership entails two sides: the leader and the follower. The followers' identification or acceptance of leader's values is necessary for leadership success. There are cases when leaders who transparently express and act upon their core values, nonetheless fail to achieve relational authenticity with their followers. A possible reason of such leadership failure may be insufficient leader's ability to articulate one's values and / or the reluctance among followers to accord the leader and promote such values on their behalf (Gardner et al., 2005).

R. Goffee \& J. Gareth (2005) possess a different attitude towards authentic leadership. The scholars state that leaders should know which personality traits they should reveal to whom and when. Effective leaders are capable to adapting to the demands of the situations they face and the people they lead, they are able to recognize which aspects of their authentic selves particular groups of followers are looking for.
There is no empirical evidence why some authentic leaders fail. The reason of such failure may lay in followers' extrinsic or intrinsic work value orientation, as defined by SDT theory. It is likely that followers with intrinsic work value orientation are more favourable towards authentic leaders, as these followers tend to be more self-expressive, attuned towards growth and development, engaged in relationship at work and share the values of authenticity. While the followers with extrinsic work value orientation tend to work for recognition, payment, career achievements and are less oriented to value driven activities, genuine relationship, i.e. authentic leadership.

Following these arguments, we formulate the fifth and sixth propositions:

Proposition 5. Followers who possess intrinsic work value orientation tend to engage in more effective authentic leaderfollower relations.

Proposition 6. Followers who possess extrinsic work value orientation tend to less engage in effective authentic leader-follower relations.

The propositions formulated in this article assess the empirical and theoretical knowledge of authentic leadership, humanistic psychology and Self-Determination theories. Further research should empirically measure and evaluate the proposed linkages of authentic leadership on follower outcomes, as conceptualized from humanistic psychology and self-determination theory.

\section{Conclusions}

The arising paradigm of authentic leadership receives a lot of attention from leadership scholars. Authentic leadership 
theory may be the solution for the unethical behaviour, short-term results, employee dissatisfaction and turnover in the organizations, as well as leaders and followers' self-actualization and well-being. The construct of authentic leadership is under development, the dimension of the construct, discriminant validity, and outcomes of authentic leadership should be defined. Little attention was drawn to the leader-follower relationship, the consequences of authentic leadership on dyadic leader-follower interaction (Eagly, 2005; Avolio et al., 2004).

Rich in empirical evidence, self-determination theory provides insights and propositions for the authentic leadership research on the outcomes of authentic leadership: followers' intrinsic motivation, followers' trust in organization, commitment and overall job satisfaction, intrinsic motivation of leaders, internalization of authentic leader values' among employees. The issue of authentic leadership impact on followers may be investigated from selfdetermination theory's conceptualization that followers are intrinsically or extrinsically work value oriented. The intrinsically oriented followers tend to be more engaged in effective authentic leader-follower relations, than the followers who possess extrinsic work value orientation.

The need for relatedness may play an important role in a variety of processes. Authentic leadership is wealthy in safe (Zhu et al, 2004; Avolio et al, 2004), meaningful (Gardner \& Avolio, 2005) and enduring (George et al., 2007) relations. Authentic leadership theory may contribute to the research of the need of relatedness within self-determination theory. The specifics of authentic leadership on the leader-follower relations and organizational contexts bring additionally needed evidence for the effects of self-determination theory in the organization (Gagne \& Deci, 2005, Kuuvas, 2009). Proposed outcomes on performance and trust among employees are the under researched topics in the area of organizational behavior (Heath \& Sitkin, 2001).

The conclusions of the article contribute to the development of authentic leadership theory and define organizational implications of authentic leadership. Future research should empirically measure and assess conceptualized proposition and establish theory outcomes in authentic leader-follower relationship.

\section{Literatūra}

1. Avolio, B. (2007). Promoting more integrative strategies for leadership theory-building. American Psychologist, Vol. 62 (1), Jan. 2007. Special issue: Leadership.

2. Avolio, B. J., Gardner, W. L. (2005). Authentic leadership development: Getting to the root of positive forms of leadership. The Leadership Quarterly. Vol. 16, 315-338. doi: 10.1016/j. leaqua.2005.03.001.

3. Avolio, B. J., Garner, W. L., Walumba, F. O. (2005). Preface. In Gardner, W. L., Avolio, B. J., Walumbwa, F. O. (Eds.) Authentic Leadership Theory and Practice: Origins, Effects and Development. Elsevier Ltd. Oxford.
4. Avolio, B. J., Gardner, W. L., Walumbwa, F. O., Luthans, F., May, D. R. (2004). Unlocking the mask: a look at the process by which authentic leaders impact follower attitudes and behaviors. The Leadership Quarterly. Vol. 11, 801-823. doi: 10.1016/j.leaqua.2004.09.003.

5. Avolio, B. J., Walumbwa, F. O., Weber, T. J. (2009). Leadership: Current Theories, Research, and Future Directions. Annual Review of Psychology. Vol. 60, Issue 1. doi:10.1146/annurev. psych.60.110707.163621.

6. Baard, P. B. (2002). Intrinsic Need Satisfaction in Organizations: A Motivational Basis of Success in For-Profit and Non-for-Profit Settings. 
In Deci, E. L., Ryan, R. M. (Eds.). Handbook of Self-Determination Research. The University of Rochester Press.

7. Barnard, C. I. (1938). The Functions of the Executive. $9^{\text {th }}$ printing. Harvard University Press. Cambridge, Massachusetts.

8. Barnard, C. I. (1948). Organization and Management. $4^{\text {th }}$ printing. Harvard University Press. Cambridge, Massachusetts.

9. Cooper, C. D., Scandura, T. A., Schriesheim, C. A. (2005). Looking forward but learning from our past: Potential challenges to developing authentic leadership theory and authentic leaders. The Leadership Quarterly. Vol. 16, 475-493. doi: 10.1016/j.leaqua.2005.03.008.

10. Deci, E. L., Connell, J. P., Ryan, R. M. (1989). Self-determination in a Work Organization. Journal of Applied Psychology. Vol. 74, No. 4.

11. Deci, E. L., Koestner, R., Ryan, R. M. (1999). A Meta-Analytic Review of Experiments Examining the Effects of Extrinsic Rewards on Intrinsic Motivation. Psychological Bulletin. Vol. 125, No. 6.

12. Deci, E. L., Ryan, R. M. (2000). The "what" and "why" of goal pursuits: Human needs and the self-determination of behavior. Psychological Inquiry. Vol. 11.

13. Deci, E. L., Ryan, R. M. (2008). Self-Determination Theory: A Macrotheory of Human Motivation, Development, and Health. Canadian Psychology. Vol. 49, No. 3.

14. Eagly, A. H. (2005). Achieving relational authenticity in leadership: Does gender matter? The Leadership Quartely. Vol. 16, 459-474. doi: 10.1016/j.leaqua.2005.03.007.

15. Endrissat, N., Muller, W. R., Kaudela-Baum, S. (2007). En Route to an Empirically-Based Understanding of Authentic Leadership. European Management Journal. Vol. 25, No. 3. doi: 10.1016/j.emj.2007.04.004.

16. Gagne, M., Deci, E. L. (2005). Self-determination theory and work motivation. Journal of organizational behavior. Vol. 26. doi: 10.1002/ job.322.

17. Gardner, W. L., Avolio, B. J., Walumbwa, F. O. (2005). Authentic Leadership Theory and Practice: Origins, Effects and Development.

18. Gardner, W. L., Schermerhorn, J. R. Jr. (2004). Performance gains through positive organizational behavior and authentic leadership. Organizational Dynamics. Vol. 33. doi: 10.1016/j. orgdyn.2004.06.004.
19. George, B., Sims P., McLean, A. N., Myer, D. (2007). Discovering Your Authentic Leadership. Harvard Business Review. Vol. 85, Issue 2.

20. Goffee, R., Gareth, J. (2005). Managing authenticity. Harvard Business Review. Vol. 83, Issue 12.

21. Harvey, P., Martinko, M. J., Gardner, W. L. (2006). Promoting Authentic Behavior in Organizations: An Attributional Perspective. Journal of Leadership and Organizational Studies. Vol. 12, No. 3.

22. Heath, C., Sitkin, S. B. (2001). Big-B versus Big-O: What is organizational about organizational behavior? Journal of Organizational Behavior. Vol. 22, 43-58.

23. Hodgins, H. S., Knee, C. R. (2002). The Integrating Self and Conscious Experience. In Deci, E.L., Ryan, R.M. (Eds.). Handbook of Self-Determination Research. The University of Rochester Press.

24. Ilies, R., Morgeson, F. P., Nahrgang, J. D. (2005). Authentic leadership and eudaemonic wellbeing: Understanding leader-follower outcomes. The Leadership Quartely, Vol. 16, 373-394. doi: 10.1016/j.leaqua.2005.03.002.

25. Jensen, S. M., Luthans, F. (2006). Entrepreneurs as authentic leaders: impact on employees' attitudes. Leadership \& Organization Development Journal. Vol. 27, No. 8. doi: 10.1108/01437730610709273.

26. Kellett, J. B., Humphrey, R. H., Sleeth, R. G. (2006). Empathy and emergence of task and relations leaders. The Leadership Quarterly. Vol. 17, 146-162. doi: 10.1016/j.leaqua.2005.12.003.

27. Kernis, M. H. (2003). Toward a Conceptualization of Optimal Self-Esteem. Psychological Inquiry. Vol. 14, No. 1.

28. Koestner, R., Losier, G. F. (2002). Distinguishing Three Ways of Being Internally Motivated: A Closer Look at Introjection, Identification, and Intrinsic Motivation. In Deci, E.L., Ryan, R.M. (Eds.). Handbook of Self-Determination Research. The University of Rochester Press.

29. Kuuvas, B. (2006a). Work performance, affective commitment, and work motivation: the roles of pay administration and pay level. Journal of Organizational Behavior. Vol. 27, No. 3. doi: 10.1002/job.377.

30. Kuuvas, B. (2006b). Performance appraisal satisfaction and employee outcomes: mediating and moderating roles of motivation. The International Journal of Human Resource Management. Vol. 17, No. 3. doi: $10.1080 / 09585190500521581$. 
31. Kuuvas, B. (2009). A test of hypotheses derived from self-determination theory among public sector employees. Employee Relations. Vol. 31, No. 1. doi: 10.1108/01425450910916814.

32. Luyckx, K., Vansteenkiste, M., Goosens, L., Duriez, B. (2009). Basic Need Satisfaction and Identity Formation: Bridging Self-Determination Theory and Process-Oriented Identity Research. Journal of Counseling Psychology. Vol. 56, No.2. doi: 10.1037/a0015349.

33. Maslow, A. H. (1970). Motivation and Personality. Harper \& Row, Publishers. New York.

34. Mazutis, D., Slawinski, N. (2008). Leading Organizational Learning Through Authentic Dialogue. Management Learning. Vol. 39 (4). doi: $10.1177 / 1350507608093713$.

35. Michie, S., Gooty, J. (2005). Values, emotions, and authenticity: Will the real leader please stand up? The Leadership Quarterly, Vol. 16, 441-457. doi: 10.1016/j.leaqua.2005.03.006.

36. Murphy, H. (2003). Intrinsic Motvation and Self-esteem in Traditional and Mature Students at a Post-1992 University in North-east of England. Educational Studies, Vo. 29.

37. Norman, S., Luthans, B., Luthans, K. (2005). The Proposed Contagion Effect of Hopeful Leaders on the Resiliency of Employees and Organizations. Journal of Leadership and Organizational Studies. Vol. 12, No. 2.

38. Nov.icevic, M. M., Davis, W., Dorn, F., Buckley, M. R., Brown, J. A. (2005). Barnard on conflicts of responsibility: Implications for today's perspective on transformational and authentic leadership. Management Decision. Vol. 43, No. 10. doi: 10.1108/00251740510634930.

39. Novicevic, M. M., Harvey, M. G., Buckley, M. R., Evans, R. (2006). Authentic Leadership: A Historical Perspective. Journal of Leadership and Organizational Studies. Vol. 13, No.1.

40. Rogers, C. R. (1980). A Way of Being. Houghton Mifflin Company.

41. Ryan, R. M., Deci, E. L (2000). Self-determination theory and the facilitation of intrinsic motivation, social development, and wellbeing. American Psychologist, 55, 68-78. doi: 10.1037110003-066X.55.1.68.

42. Ryan, R. M., Deci, E. L. (2002). Overview of SelfDetermination Theory: An Organismic Dialecti- cal Perspective. In Deci, E. L., Ryan, R. M. (Eds.). Handbook of Self-Determination Research. The University of Rochester Press.

43. Shamir, B., Eilam, G. (2005). "What's your story?" A life-stories approach to authentic leadership development. The Leadership Quarterly. Vol. 16. doi: 10.1016/j.leaqua.2005.03.005.

44. Shirey, M. R. (2006). Authentic Leaders Creating Healthy Work Environments for Nursing Practice. American Journal of Critical Care. Vol. 15.

45. Sparrowe, R. T. (2005). Authentic leadership and the narrative self. The Leadership Quarterly. Vol. 16, 419-439. doi: 10.1016/j.leaqua.2005.03.004.

46. Taylor, Ch. (1995). The Ethics of Authenticity. Harvard University Press.

47. Vallerand, R. J., Koestner, R., Pelletier, L. G. Reflections on Self-Determination Theory. Canadian Psychology. Vol. 49, No. 3. doi: 10.1037/ a0012804.

48. Vallerand, R. J., Ratelle, C. F. (2002). Intrinsic and Extrinsic Motivation: A Hierarchical Model. In Deci, E. L., Ryan, R. M. (Eds.). Handbook of Self-Determination Research. The University of Rochester Press.

49. Vansteenkiste, M., Neyrinck, B., Niemec, C. P., Soenens, B., De Witte, H., Van den Broeck A. (2007). On the relations among work value orientations, psychological need satisfaction and job outcomes: A self-determination theory approach. Journal of Occupational and organizational Psychology. Vol. 80. doi: 10.1348/096317906X111024.

50. Verbos, A. K., Gerard, J. A., Forshey, P. R., Harding, C. S., Millers, J. S. (2007). The Positive Ethical Organization: Enacting a Living Code of Ethics and Ethical Organizational Identity. Journal of Business Ethics. Vol., 76, Issue 1. doi: 10.1007/s10551-006-9275-2.

51. Walumbwa, F. O., Avolio, B. J., Gardner, W. L., Wernsing, T. S., Peterson, S. J. (2008). Authentic Leadership: Development and Validation of a Theory-Based Measure. Journal of Management, Vol. 34, No. 1. doi: 10.1177/0149206307308913.

52. Zhu, W., May, R. D., Avolio B. J. (2004). The Impact of Ethical Leadership Behavior on Employee Outcomes: The Role of Psychological Empowerment and Authenticity. Journal of Leadership and Organizational Studies. Vol. 11, No.1.

The paper submitted: September 25, 2012

Prepared for publication: October 28, 2013 
Alisa MINIOTAITĖ, Ilona BUČIŪNIENĖ

\section{AUTENTIŠKOS LYDERYSTĖS PASEKMIŲ AIŠKINIMAS, REMIANTIS SELF-DETERMINATION (APSISPRENDIMO) TEORIJA}

\section{$S$ u $\mathrm{m}$ m a r y}

Autentiškos lyderystès teorija pastaraisiais metais sulaukia vis daugiau tyrèjų démesio. Tai viena labiausiai dominuojančių lyderystès teorijų lyderystès tyrimų kontekste. Nepaisant to, dauguma publikuojamų straipsnių apie autentišką lyderystę yra teoriniai, skirti autentiškos lyderystès konstrukto konceptualizavimui. Šiandien pagrindiniai autentiškos lyderystès mokyklos uždaviniai yra konstrukto formulavimas, konstrukto diskriminantinio validumo nustatymas, autentiškos lyderystès pasekmių, priklausomų kintamụjų identifikavimas (Walumbwa ir kt., 2008; Novicevic ir kt., 2006; Cooper ir kt., 2005). Pripažistama, kad autentiškos lyderystès poveikis organizacijos ir darbuotojų elgsenai yra nepakankamai nagrinètas (Jensen ir Luthans, 2006; Gardner ir kt., 2005; Illeis ir kt., 2005; Avolio ir kt., 2004).

Šiame straipsnyje analizuojamas autentiškos lyderystès poveikis pasekejui, remiantis Self-Determination (liet. Apsisprendimo) teorija, kuri aiškina, kaip ir kodèl individo elgesys yra save skatinantis (angl. self-endorsed) ir paremtas apsisprendimu (angl. self-determined) (Deci ir Ryan, 2002). SDT dèmesys skiriamas vidinei ir išorinei žmogaus motyvacijai. Kompetencijos, autonomijos ir artimo ryšio poreikiai - tai poreikiai, kurie skatina individą veikti ir prisideda prie psichologinio augimo (Luyckx ir kt., 2009; Vallerand ir kt., 2008; Hodgins ir Knee, 2002; Ryan ir Deci, 2002). Vienas iš autentiškumo šaltinių - apsisprendimo laisvè arba autonomija (Taylor, 1991). Autentiška lyderyste skatindama lyderių ir pasekejjų autonomiją bei kurdama saugius santykius įtakoja pasekejjų vystymąsi.

Straipsnyje analizuojama, kaip autentiškos lyderystès ir Self-Determination teorijos yra tarpusavyje susijusios ir gali tarnauti nustatant autentiškos lyderystės teigiamą įtaką pasekèjų vidinei motyvacijai, pasitikejjimui, ịsipareigojimui ir bendram pasitenkinimui darbu, taip pat lyderių vidinei motyvacijai ir autentiškos lyderystès vertybių internalizavimui tarp pavaldinių. Straipsnyje pateikiamas aiškinimas, kodèl ne visuomet autentiška lyderystė gali būti sẻkminga. Pirmą kartą moksliniam diskurse detalizuojama, kaip autentiškos lyderystès sèkmé gali priklausyti nuo vidinès ir išorinès pasekejų motyvacijos. Formuluodamas autentiškos lyderystès poveikio pasekejjams ryšius, remiantis Self-Determination teorija, šis straipsnis prisideda prie autentiškos lyderystès teorijos vystymo. 